Published on Reviews in History (https://reviews.history.ac.uk)

\title{
1641 in Irish History
}

Review Number: 1772

Publish date: Thursday, 4 June, 2015

Author: John Gibney

ISBN: 9780299289546

Date of Publication: 2013

Price: $£ 25.95$

Pages: 229pp.

Publisher: University of Wisconsin Press

Publisher url: http://uwpress.wisc.edu/books/4963.htm

Place of Publication: Wisconsin

Author: Jane Ohlmeyer

Date of Publication: 2014

Publisher: Trinity College Library

Place of Publication: Dublin

Reviewer: Gerald Power

In 1966 the historical profession was deprived of a talented and original practitioner, when Dr Walter Love was killed in a traffic accident. Utah-born Love was drawn towards Irish history following his postgraduate research into Edmund Burke, and ultimately his interest centred on how the events of 1641 had become engrained into collective memory in Ireland. Love perceived a striking continuum in Protestant and Catholic accounts of the uprising from the 1640s to the 20th century: 17th-century pamphleteers and clerics, Enlightenment scholars and even Rankean historians were seemingly unable to view the insurrection without resorting to rival confessional or national lenses. Walter Love died before his researches could be developed and placed before the public; but his papers were entrusted to the library at Trinity College Dublin, and now former Trinity student John Gibney has completed Love's unfulfilled task.

Gibney has done ample justice to Love's vision. The Shadow of a Year is an ambitious and persuasive book, written with concision and verve. Its analysis of the reception of the 1641 rising in Irish discourse ranges across four centuries and draws upon sources as varied as contemporary pamphlets, broadsides, newspaper and journal articles, speeches, histories of various kinds, ballads, poetry and fiction. The book establishes the 1641 rising as a preeminent Irish lieu de memoire. Not only was the memory of 1641 central to the development of the sectarian divide in Ireland, it has repeatedly been corralled into service by the more ardent partisans; Gibney's achievement is to explain the circumstances under which successive generations of commentators have recalled and interpreted the rebellion, and the forms these interpretations have taken.

By way of introduction, the events of 1641 are briskly summarised along with a discussion of the so-called depositions. These witness statements are of course at the crux of the 1641 controversy, in particular the small number of testimonies that contain lurid accounts of innocent Protestants suffering torture and murder at the hands of their Catholic neighbours. Mendaciously employed by contemporary statesmen Dean Henry Jones and Sir John Temple, the depositions and the memory of atrocity they supposedly enshrined formed a vital foundation of the anti-Catholic settlements established in Ireland in the years after 1641. In a 
remarkably short space of time, the rising had become a myth.

The myth was especially important for the Protestants of Ireland. Gibney shows how during the turbulent years of the Commonwealth and the Restoration, Irish Protestants returned to 1641 in order to lend credence to their continued appeals to the English authorities that the Catholics of Ireland were not to be tolerated with political power. During subsequent crises, including the Tyrconnell lieutenancy, the Williamite War and later Jacobite scares, Protestants kept the memory of 1641 alive in order to help safeguard their ascendant position. Meanwhile, the fact that the anniversary of the rebellion was commemorated by the ringing of church bells, bonfires and sermons indicates that the memory of 1641 had a utility for a broad social spectrum of Protestant Ireland.

For obvious reasons, Irish Protestants were more interested in the rebellion than their British counterparts. But English writers including Milton and Defoe also referred to the rising, while David Hume helped to reinforce and give Enlightenment kudos to the Jones-Temple version by sustaining that the rising was a genocidal attack by religious extremists. From the mid-18th to the mid-19th centuries new problems facing Irish Protestants - especially the Catholic Question - prompted them to reflect again on 1641. Here the key role was played by Richard Musgrave, whose Memoirs of the Different Rebellions in Ireland (1801) concluded that the 1798 United Irishmen rebellion was merely a reprise of 1641. Although this book is anything but dull and moves at a cracking pace, at times this survey of Protestant opinion is a little breathless, with Defoe and Milton's views, for instance, dispatched in a single paragraph. I also wonder if it is possible that additional evidence would have been found in the abundant travel literature on Ireland published in the 18th and 19th centuries, at least some of which includes reflections on the island's 17thcentury history.

A discussion of the inevitable Catholic riposte follows. It is demonstrated that for the first century after 1641, Catholic texts, most notably Hugh Reilly's Ireland's Case Briefly Stated (1695), focused on exculpating the Catholics from guilt and emphasising the loyalty of Catholics to the British monarchy. Catholic authorities claimed that the attacks on Protestants had been provoked, with some making reference to an apparent massacre of Catholics in Islandmagee, County Antrim, that may have predated the Catholic assaults. These accounts also denied the clearly inflated numbers of Protestant fatalities contained in the versions of Temple and his followers. And the rehabilitation of Catholics was complete by the assertion that Catholics in 1641 had been acting in the interests of King Charles while the Protestants of Ireland were representatives of a parliamentary conspiracy.

John Curry's Brief Account of 1747 is shown to have been of seminal importance in the development of the Catholic attitude towards 1641. Not only did it deny that any massacre of Protestants took place, it referred to the depositions, which since the writings of Jones and Temple had been gathering dust in private collections before being presented to Trinity College Dublin in 1741. Curry sceptically scrutinized the evidence marshalled by Jones and Temple, including the account of the ghosts of Protestant dead haunting the scene of their destruction in Portadown, to make an important general point: that the existing constitution of Ireland, including of course the penal laws, was based upon a conscious distortion of the historical record. Gibney shows that in the context of Enlightenment concern for good government and scholarly values, Curry's critique of the standard Protestant interpretation of 1641 gained traction even among Protestants. Among these was the English clergyman Ferdinando Warner, whose drive to come to an impartial understanding of the rebellion prompted him also to examine the depositions, albeit rather superficially. After so much polemic, Warner's conclusion that 'the truth is, the soldiers and the common people were very savage on both sides' (p. 92) is distinctly refreshing. 
The latter part of the discussion of the Catholic riposte changes pace from the rarefied atmosphere of Enlightenment scholarship to address various 'popular' Catholic understandings of the rebellion, using school texts, ballads, histories and novels, to show how the rebellion became incorporated into burgeoning popular nationalist versions of Irish history. By the mid-19th century, the rising could be seen - as in the 1864 novel Confederate Chieftains - as the first popular nationalist rising.

The final chapter examines how the rebellion was interpreted during the age of professional history, and attempts to solve one of the key challenges that Walter Love had set himself in the 1960s: why professional historians using modern historical methodology had apparently failed to come to a neutral, myth-free understanding of 1641. It opens with a discussion of the Catholic antiquarian J. P. Prendergast, the first scholar of 1641 to really dedicate himself to a study of the primary sources. While Prendergast's work was essentially a more sophisticated update of the standard Catholic interpretation, James Anthony Froude's observations in his The English in Ireland (1872-4) were intensely vituperative and racist. Meanwhile, it appears that more neutrally-minded scholars were disinclined to participate in the controversy. W. E. H. Lecky condemned Froude, but neither he nor the Manchester historian Robert Dunlop were willing to systematically interrogate the depositions; Dunlop kicked for touch, claiming that 'it is impossible to make any historical use of [the depositions] without making very considerable deductions owing to the circumstances under which they were taken' (p. 136). J. C. Beckett also skirted the issue in his 1966 A Short History of Ireland. Nevertheless, a welter of interested commentators from outside the academy needed little encouragement to take up the challenge. These included authors influenced by Rankean methods such as Mary Hickson and Thomas Fitzpatrick; politicians such as the Home Ruler Justin McCarthy; and the aristocratic amateur historian Lord Ernest Hamilton. All contributed interpretations of 1641 that amounted to little more than 'regressions' - 'traditional accounts ... in newer garb' (p. 139). Thus, the advent of scientific history failed to lead to a conclusion to a controversy which, as discussed in the Conclusion, was to be depressingly absorbed into the polarised discourse of the Troubles.

I am not completely persuaded by this chapter. First - if I understand correctly - it rests on the assumption that the advent of scientific historical methods means that we should expect deeply-entrenched and partisan interpretations of the 1641 rising to wither away. But is it really surprising that the Home Rule crisis, the Irish wars of 1916-23 and partition were as important a set of influences on these authors as the expansion of academic history, with the result that 1641 was either grist to the mill for the amateur-partisans or an intolerable responsibility for the professionals? Moreover, as Michael Gove's recent statements on the meaning of World War I show, even a politician with an appreciation for and an understanding of professional history must be assessed as a politician first and foremost and not as an historian; a politician's agenda-driven pronouncements on the past does not mean that professional history is incapable of conveying truth. Finally, as the chapter's title gives c.1965 as its terminal date, a more extensive treatment of the historiography in the period from the 1930s to the 1960s would have been welcome, especially as these years bore witness to a conscious attempt by a group of Irish historians to purge the country's history of sectarian-nationalist myths; this is a development mentioned in the Introduction, but not followed through later. The flagship publication of the movement, Irish Historical Studies, does not receive a mention.

But these objections do not seriously detract from a book brimming with learning and sympathy. This fascinating account of how the rebellion has resonated through four centuries of historiography and popular memory will surely attract a large audience among historians, cultural students and the educated general reader.

Of course, a major question remains: what actually happened in 1641? As Gibney's study points out, the depositions have been referred to far more than they have been consulted. Certainly, there were formidable obstacles for scholars to overcome, not least of which was the sheer bulk of the evidence: the approximately 8,000 testimonies - of which a great many are less than legible - occupy an immense 31 misleadinglyarranged volumes and 19,010 pages. Now, however, thanks to Trinity College Dublin's 1641 Depositions website [3], both modern transcriptions and state-of-the-art facsimiles of each statement have been made 
freely available. It is a hugely impressive achievement. The website is easy to navigate and researchers have a wonderful array of fields to choose from when using the 'search' facility, including names of people and places, occupation, religion, age range, sex, nature of deposition and date. The website also features around a dozen short essays which provide essential information on the documents themselves as well as the wider historical context. (One minor quibble here is the presence of a small number of grammatical and punctuation mistakes: a copy editor is needed to purge these irritants.)

It is unlikely that the 1641 Depositions project will resolve fully the controversies explored in Shadow of a Year - if only because Catholic testimonies are so few. However, researchers using the website have already begun to shed more light on a number of aspects of the rebellion, from rebel leadership and organisation to the experience of the rising in plantation towns and other localities.(1) Just as important, the website also permits researchers to elaborate on the pioneering work of Nicholas Canny and exploit more fully the depositions' value as a unique window into the society and economy of early 17th-century Ireland.

Students of 17th-century British and Irish history will surely be grateful that John Gibney delved into the 40year-old papers of Walter Love, and that the initiators of the 1641 Depositions project secured funding for their work just at the moment when the Irish economic boom was at its height.

\section{Notes}

1. The 1641 Depositions and the Irish Rebellion, ed. Eamon Darcy, Annaliegh Margey and Elaine Murphy (London, 2012). Back to (1)

\section{Other reviews:}

Sehepunkte

http://www.sehepunkte.de/2014/07/24344.html [4]

Source URL:https://reviews.history.ac.uk/review/1772

\section{Links}

[1] https://reviews.history.ac.uk/item/63589 [2] https://reviews.history.ac.uk/item/63590 [3] http://1641.tcd.ie/ [4] http://www.sehepunkte.de/2014/07/24344.html 